\title{
Arşiv Belgelerine Göre Cumhuriyetin İlk Yıllarında Doğu Türkistan'ın Genel Durumu ve Türkiye ile Kültürel Münasebetler ${ }^{*}$
}

\section{Muzaffer Başkaya**}

$00 \mathrm{z}$

Türkiye Cumhuriyeti Devleti'nin kurucuları Cumhuriyetin ilanından bir süre sonra dünyanın çeşitli bölgelerine dağılmış Türklerle siyasi ve kültürel iş birliğini geliştirmek amacıyla bazı adımlar atmıştır. Bu maksatla Doğu Türkistan ve burada yaşayan soydaşların durumuyla yakından ilgilenilmiş ve bölgeyi iyi bilen kişilere raporlar hazırlatılmıştır. Bunlardan biri de Mecdettin Delil tarafından kaleme alınan rapordur. Bu raporda Doğu Türkistan'ın o günkü siyasi, ekonomik ve kültürel durumuyla ilgili tafsilatlı bilgiler verilmiş, bilhassa Türkistan'dan dışarıya göç eden muhacirlerin vaziyetleri üzerinde durulmuş, Türkiye ile Doğu Türkistan arasındaki kültürel bağların kuvvetlendirilmesi gerektiği ifade edilmiştir. Bu raporun ardından harekete geçen Türk Hükümeti, bölgede yaşayan Türk unsurlara yeni rejimi tanıtmak, onlarla bir gönül köprüsü inşa etmek için çalışmıştır. Bu maksatla bölgeye yeni harfler gönderilmiş, oradan öğrenciler getirilerek Türkiye'de okutulmaları sağlanmış, bölgede gazete ve dergi çıkarmak suretiyle Türkiye’nin tanıtımı yapılmaya çalışılmıştır. Böylece Çin egemenliği altında yaşayan soydaşlara dostluk eli uzatılmış ve bu bölgede kendi hegemonyasını kurmak isteyen Çin yönetiminin baskısı kırılmaya çalışılmıştır.

\section{Anahtar Kelimeler}

Doğu Türkistan, muhacir, basın-yayın, Latin harfleri, kültür, tanıtım.

Geliş Tarihi: 21 Nisan 2017 - Kabul Tarihi: 07 Şubat 2018

Bu makaleyi şu şekilde kaynak gösterebilirsiniz:

Başkaya, Muzaffer (2019). “Arşiv Belgelerine Göre Cumhuriyetin İlk Yıllarında Doğu Türkistan’ın Genel Durumu ve Türkiye ile Kültürel Münasebetler”. bilig - Türk Dünyast Sosyal Bilimler Dergisi 89: 215-236.

** Dr. Öğr. Üye., Trabzon Üniversitesi, Fatih Eğitim Fakültesi, Türkçe ve Sosyal Bilimler Eğitimi Bölümü - Trabzon/Türkiye ORCID ID: https://orcid.org/0000-0002-4593-0979 mbaskaya61@gmail.com.tr 


\section{Giriş: Doğu Türkistan'ın Kısa Tarihi}

Türklerin en eski yerleşme alanlarından biri olan Doğu Türkistan, Orta Asya Türk tarihinin bir parçası olarak Hun ve Göktürk İmparatorluklarının sınırları içerisinde yer almıştır. 742 senesinde Basmıl, Uygur ve Karluklardan müteşekkil boylar Göktürk Devleti' ni yıkmışlar, 744 yılında ise bu boylardan Uygurlar Ötüken'de hâkimiyetlerini sağlayarak Uygur Hakanlığını kurmuşlardır. Uygur Devleti 840 yılında Kırgızlar tarafından yıkılınca geriye kalan Uygurlar Asya’nın daha güney bölgelerine Çin' in batısına yerleşerek Kan-Cou ve Doğu Türkistan (Turfan) Uygur Devletini kurmuşlardır. Bu olay aynı zamanda Doğu Türkistan Uygur tarihinin de başlangıcıdır (Kafesoğlu 1993: 129). Doğu Türkistan'da Karahanlılar'ın hâkimiyet kurmasıyla birlikte bölge İslam'la tanışmış, daha sonra burası sırasıyla Karahıtaylar ve Moğollara tabi olmuştur. Ardından Timur'un hâkimiyet kurduğu Doğu Türkistan, Çağataylılardan Emir İsmail'in eline geçmiş ve böylece Hocalar Hanedanlığı adı verilen ve 1755 yılına kadar sürecek olan dönem başlamıştır (Gömeç 1998: 74).

XVIII. yüzyılda Doğu Türkistan'ın Kumul ve Turfan kasabalarını ele geçiren Mançu-Çin orduları 1754'te Kalmuklar'ı yenmiş, 1759'da tam bir karışıklık içindeki Kâşgar ve civarını işgal etmiş, bunun üzerine 1760'lı yıllarda Kazaklar'ın Orta ve Küçük cüzleriyle Hokand Hanları da Çin'in üstünlüğünü kabul etmek zorunda kalmıştır. Direniş ve kurtuluş çarelerinin arandığı fakat genel olarak esaret ve baskı altında geçen bir asırlık sürecin ardından Doğu Türkistan, Yakup Han'ın üstün gayreti ile tekrar Türklerin idaresi altına girmiştir. Ancak Çinliler, uğradıkları ağır yenilgilerin intikamını almak ve Doğu Türkistan'ı yeniden istilâ etmek için Rusların da yardımıyla harekete geçmiştir. Çin ordusu 17 Ağustos 1876 'da Urumçi üzerinden ilerleyerek Yakup Han'ın ölümünden sonraki karışıklığın da etkisiyle Aralık 1877’de Kâşgar dâhil bütün Doğu Türkistan'ı işgal etmiştir (Taşağıl 2012: 558-559). 18 Kasım 1882 yılında bölgede Türk hâkimiyetini tamamıyla sona erdirmek amacıyla Çin İmparatorunun emriyle Doğu Türkistan'ın adı Çin'in 19. eyaleti olarak Yeni Toprak anlamına gelen Hsin-chiang olarak değiştirilmiştir. Okunuşu genel olarak Yeni Toprak, Yeni Hudut olsa da Çincenin yazı özelliklerinden hareket edildiği takdirde işbu yer adının "Yeniden silah gücü ile ele geçirilen toprak” anlamına geldiği anlaşılmaktadır. Çinliler, bölgedeki Türk kimliğini ortadan kaldırmak amacıyla Doğu Türkistan adının kullanılmasını yasaklamış, 
kullananları ise acımasızca cezalandırmıştır (Türkler 2015: 27). Çinliler 1884 yılında da bölgede Doğu Türkistan (Xinjiang / Sincan) eyaletini kurmuşlardır.

Doğu Türkistan'daki Çin egemenliği 1930'lu yıllara kadar devam etmiş, 1931'de başlayan ve iki yıl süren Kumul isyanı sonucu 12 Kasım 1933'te Kaşgar'da resmen Doğu Türkistan İslam Cumhuriyeti kurulmuştur. Fakat bu idare üç cephede birden mücadele etmek zorunda kalmıştır. Bunlar, Çinliler, Ruslar ve uzun yıllardır Doğu Türkistanlıların başına dert olan Döngenler. Zira bu grup Doğu Türkistan’a hâkim olabilmek için bölgedeki Türklere savaş ilan etmiş, Doğu Türkistan İslam Cumhuriyeti lideri Hoca Niyażın hataları (Saray 1995: 159-160) ve devamında Çinlilerden destek alan Sovyet ordularının bölgeye girmesiyle birlikte Doğu Türkistan'daki Türk idaresi tekrar kesintiye uğramıştır (Emet 2002: 476). Bu olaylardan yaklaşık on yıl sonra 1944 'te çıkan ayaklanmalar neticesinde 12 Kasım 1944'te Şarki Türkistan Cumhuriyeti ilan edilmiş, bu oluşum da ancak beş yıl ayakta kalabilmiş, bu dönemde Üç Efendiler olarak bilinen ve genellikle Çin’e yakın duran İsa Yusuf Alptekin, Mehmet Emin Buğra, Mesut Sabri yönetimde etkin rol oynamış fakat 1949'da Komünist Çin ordularının işgali sonucunda Mehmet Emin Buğra ve İsa Yusuf Alptekin olmak üzere binlerce Uygur ve Kazak Türkü Hindistan ve Pakistan'a, oradan da Türkiye'ye göç etmiştir. Bu tarihten sonra Komünist Çin, Doğu Türkistan'da Türk ve İslam varlığını ortadan kaldırmak için değişik metotlar denemiş, Türk kimliği silinmeye çalışılmış, İslam eserlerinin okunması yasaklanmış, çeşitli yöntemlerle milliyetçi Uygurlara ağır hapis, işkence ve idam cezaları uygulanmıştır (Anat 2005: 175-178).

\section{Mecdettin Delil ve 1940 Tarihli Raporu}

Doğu Türkistan'ın vaziyeti ve bağımsızlık mücadelesi Türkiye Cumhuriyeti için de önem taşıyan bir durumdu. Bilhassa Doğu Türkistan'dan Türkiye’ye hicret etmek zorunda kalan aydın ve yazarlar ülke içinde kamuoyu yaratıp belli bir bilinç uyandırmak için büyük gayret sarf etmişlerdir. Bu kapsamda Yeni Türkistan, Odlu Yurt, Bildiriş gibi yayınlar çıkarılmıştır. Bu faaliyetler Türk-Sovyet ilişkilerinin seyrine göre Türk Hükümetinden bazen destek görmüş bazen de bu gibi yayın ve girişimler yasaklanmıştır (Çınar 2012: 6).

Doğu Türkistan'dan hicret ederek Türkiye’ye gelip mücadelesine burada devam eden vatanseverlerden biri de Mecdettin Delil'dir. O bölgenin bir evladı olan Mecdettin Bey 1902 yılında Taşkent'te doğmuştur. Liseyi memleketin- 
de bitirmiş ardından Cumhuriyetin ilan edildiği 1923 senesinde Türkiye’ye gelmiş, daha sonra Diş Hekimliği Fakültesine girmiştir. 1926 yılında okulu bitirerek diş hekimi olmuş, diğer yandan da Doğu Türkistan'ın bağımsızlığı için Türkiye'de yürütülen faaliyetlerin içerisinde bulunmuştur (Andican 2003: 308). Genel olarak Mustafa Çokayoğlu ile birlikte bu hareketin içinde yer alan Mecdettin Bey 1927 yılında Türkistan Türk Gençler Birliği adıyla kurulan derneğin başkanı seçilmiştir. Yeni Türkistan Dergisi'nde müdürlük yapmış, Türkistan Milli Birliği adlı cemiyetin içinde Hizip adıyla bilinen yenilikçi bir grubun içinde yer almıştır. 1931 yılında yönetiminde yer aldığı Yeni Türkistan Dergisi'nin Türk Hükümeti tarafından kapatılması sonucu Türkistan Milli Birliği Genel Sekreteri, Türkistan Türk Gençler Birliği Başkanı ve Yeni Türkistan Dergisi sorumlusu olarak hükümet nezdinde yaptığı müracaatlar sonuçsuz kalmış, yapılan başvurulara resmi makamlarca cevap dahi verilmemiştir (Andican 2003: 365).

Mecdettin Delil en zor yıllarını 1933 sonrasında yaşamıştır. Bu dönemde Doğu Türkistan istiklal hareketinin organizasyonu için Japonya ve İngiltere Hükümetleri nezdinde girişimlerde bulunan Türkistan Milli Birliği bu faaliyetlerden netice elde edemeyince meseleyi kendi imkânlarıyla yönetme kararı almış ve bu kapsamda Genel Sekreter Mecdettin Delil'in Doğu Türkistan'a gitmesi ve bölgede Doğu Türkistan'ın istiklali yönünde çalışmalarda bulunmasına karar verilmiştir. Bu kararın ardından Mecdettin Bey 1933 yılı Eylül ayında İstanbul'dan Hindistan'a hareket etmiş, seyahat amacını gizlemek ve temaslarını kolaylaştırabilmek için Akşam Gazetesi muhabiri gibi bir gazeteci kimliği çıkartmıştır. 1934 yılı başlarında Peşaver üzerinden Doğu Türkistan’a geçmiş, fakat Kaşgar'a ulaşmasının ardından burada tutuklanmıştır. Doğu Türkistanlı General Mahmut Muhiti’nin Kaşgar şehrini ele geçirmesine kadar hapiste kalan Delil, özgürlüğüne kavuştuktan sonra yaklaşık 3 yıl boyunca General Muhiti ile birlikte hareket etmiş, bir taraftan da Kaşgar'daki bazı okullarda eğitim öğretim konusunda çalışmalar yapmıştır. Fakat gelişen olaylar neticesinde Doğu Türkistan mücadelesinin başarısız olacağını anlayan Mecdettin Delil, 3 yıl sonra 1937 yılı ortalarında Hindistan üzerinden tekrar Türkiye’ye geri dönmüştür (Andican 2003: 384-385).

Mecdettin Delil, Türkiye’ye dönüşünün ardından 1940 yılında resmi makamlara ulaştırılması için bir rapor kaleme almış, raporda Doğu Türkistan Türklerinin ekonomik, sosyal ve kültürel sorunları hakkında bilgiler vermiştir. 
Çalışmamızın temelini oluşturan bu raporda, Türkistan coğrafyasında bulunan Türklerin Rus ve Çin baskısı altında yaşamaya mecbur bırakıldıkları ve bu baskıdan kaçanların Afganistan ve Hindistan'a hicret ettikleri, bölgede kültürel anlamda büyük bir baskı mekanizmasının kurulduğu, bölgedeki Türklerin Türkiye'den yardım görmemeleri halinde bugünkü vaziyetlerini dahi arayacakları ifade edilmiştir.

Çalışmanın son kısmında Mecdettin Bey'in kaleme aldığı raporun etkisiyle Türk Hükümeti'nin Doğu Türkistan'da yaşayan Türklerle kültürel münasebetleri geliştirme çabalarına değinilmiştir. Zira ortak bir kültürel geçmişe sahip olunduğu bilinciyle hareket eden Türk Hükümeti, ilk olarak bu bölgede yaşayan soydaşlara yeni harfleri göndermiştir. Ardından Türkçenin bu bölgelerde daha yaygın hale getirilmesi için kitap çıkarılmasına veya orada neşredilen Yurt Mecmuasinın desteklenmesine karar verilmiş, (BCA. 030.10/257.728.16) Türklerin kimliklerini kaybetmemeleri için Cumhuriyet Halk Partisi ve Halkevleri gibi kurumların onayıyla milli duyguları pekiştirici muhteviyata sahip çeşitli yayınlar buraya gönderilmiştir (BCA. 030.10/257.728.17). Sürecin son halkasını ise buradan getirilen öğrenciler oluşturmuştur. Zira Türk Hükümeti, Çin Türkistan'ın da yaşayan genç yaştaki öğrencileri Türkiye’ye getirterek onların burada eğitim almalarını sağlamış (BCA. 490.01/1197.194.1) böylece bir anlamda Doğu Türkistan ile Türkiye arasında kültürel bir köprü inşa edilmeye başlanmıştır.

Ömrünü Doğu Türkistan’ın bağımsızlığına adayan kişilerden biri olan Mecdettin Delil'in Başvekâlete gönderdiği rapor, söz konusu bölgenin o günlerdeki durumuna ş̧ık tutması açısından kayda değer bir nitelik taşımaktadır. Türkiye Cumhuriyeti'nin hem de İkinci Dünya Savaşı yıllarında Doğu Türkistan Türkleri ile ilgilenmesi, bu konuda raporlar hazırlatılması, bölgeyle bir şekilde irtibata geçilerek milli ve manevi değerlerin yükseltilmeye çalışılması üstelik bunların devletin resmi kayıtlarına geçecek kadar bilinçli ve bir programa göre yürütülmesi bu bölgeyle ilgilenen hemen her araştırmacı için cazip bir durum teşkil etmektedir. Bu kapsamda Cumhuriyetin ilk yıllarında Doğu Türkistan ile Türkiye Cumhuriyeti arasındaki ilişkilerin genel durumunu anlamak bu çalışmanın temel amacını oluşturmaktadır. Başbakanlık Cumhuriyet Arşivi'nden elde edilen arşiv vesikalarına dayanan bu çalışma, bu konuyla ilgili var olan literatüre katkı sağlamayı amaçlamaktadır. 


\section{Cumhuriyetin İlk Yıllarında Doğu Türkistan Türklerinin Genel Durumu}

Doğu Türkistan macerasının ardından Türkiye dönen Mecdettin Delil, İkinci Dünya Savaşı yıllarına rastlayan 1940 senesinde Türk Hükümetine sunulmak üzere oldukça uzun bir rapor kaleme almıştır. Türkistan Türk Gençler Birliği kurucularından Diş Doktoru Mecdettin Delil tarafından yazılan raporun ilk kısmında Şarki Türkistan Hakkında Kısaca Umumî Malûmat başlığı ile Doğu Türkistan’ın o günkü vaziyeti hakkında bilgiler verilmiştir. Burada verilen bilgilere göre, Doğu Türkistan, bir milyon yedi yüz bin kilometre genişliğinde takriben yedi- sekiz milyon Türkü barındıran bir ülke idi ve Tayansan (Tanrı) dağlarının kuzey ve batı istikametinde ikiye böldüğü bu Türk ülkesinin güney tarafı Altı şehir yahut Kağşaya, kuzey tarafı da Çıngara namını almıştır. Güneydeki meşhur Taklamakan Çölü hariç her taraf verimli arazi olup, güney dağlarından ziyade kuzey dağları daha müsait olduğundandır ki kuzeyde ziraattan ziyade hayvancılık daha büyük ilgi görmüştür. Rapora bakılırsa arazinin sadece yer üstü zenginliği değil aynı zamanda yer altı serveti de dikkat çekiciydi. Zira Hotan ve Zerefşan Nehirlerinden çıkarılan reg dedikleri kum halindeki altın madeni dişında dağlık bölgelerde kömür ve neft kaynakları bulunuyordu ve bunlar öteden beri Çin ve Rusya’nın bölgeye olan ilgisini artırmışı (BCA. 490.1.0/1197.194.1).

1940 tarihli raporda Doğu Türkistan'ın genel durumu hakkında ayrıca şu ifadelere yer verilmiştir:

Doğu Türkistan nüfusunun \%2-3 civarında kısmı Moğol ve Kalmuk olup Kansu ve Sucu taraflarından gelen az sayıda Döngenler, Doğu Türkistan’ın kuzey kısmındaki bazı şehirlerde toplu olarak, güney kısımlarda ise dağınık otururlardı. Döngenler lisan-yaşayış ve diğer ananece Çinlilere pek yakın olduklarından, dinî yakınlıklarına rağmen, kendilerini Türklerden ziyade Çinlilere yakın görür ve onlarla beraber yaşamayı tercih ederdi. Güneyde çok az sayıda Moğol ve Kalmuklar yaşar, burada bulunan Çinliler ise daha çok memurluk yapardi.

Raporda yer verilen iddiaya göre son dönemlerde Doğu Türkistan'daki Çinli sayısını artırmak için bazı adımlar atılmış, özellikle Çin’in değişik bölgelerinden muhacirler getirtilmiştir. Örneğin geçen yıl (1938 veya 1939) Kansu yolu ile on binlerce Çin muhaciri Türkistan'a geçirilmiş, bunların yatak, erzak vesaire ihtiyaçları ve masrafları yerli Türk halkının üstüne yıkılmış, Türk 
köylüsünün yeri gasp edildiği gibi ekecek tohumuna dahi el konulmuştur. Mecdettin Bey'in iddiasına bakılırsa bu kirli işlerde Çinlilerin en büyük yardımcıları ise Döngenler olmuş, bu topluluk Çinlilerle yakınlıkları yüzünden öteden beri yerli Türklerle iyi geçinememişler ve eskiden beri Türklerin bu bölgedeki mücadelelerinde onlara ihanet etmişlerdi. Raporda belirtildiğine göre, Çin'de çok sayıda Döngen vardı ve bunlar başlıca Kansu, Sucu, Gulca eyaletlerinde toplu ve dağınık surette yaşıyorlardı. Lisan, giyiniş ve âdet itibarryla Çinlilerden farksız olan bu Döngenlerin Çinlilere gösterdikleri sadakat neticesi olarak generalliğe ve diğer mülkî memuriyetlere yükselenleri de bulunuyordu. Raporda Döngenlerle ilgili verilen bir başka bilgi de ise onların Araplara karşı büyük bir hayranlık beslediği, her Arabı peygamberin evladı diye karşıladığı ve hürmet ettiği, bunlara ek olarak Arapça öğrenip Kuran okudukları belirtilmiştir. Rapora göre, mizaç ve tabiat itibarı ile de Çinliler gibi sinsi, tembel ve entrikacı olan Döngenler, Araplar tarafından da çok sevilip takdir görüyorlardı (BCA. 490.1.0/1197.194.1).

Raporda Döngenlerin, Doğu Türkistan’ın bağımsız kaldığı kısa süre boyunca yaptığ 1 faaliyetlerle ilgili şu ifadelere yer verilmiştir:

Burada şu acı hakikati tebarüz ettirmek isteriz ki Türk ülkesinde Türk unsurunun büyük fedakârlıklarla kendi ruh ve ananesine uygun olarak vücuda getirdiği cumhuriyet idaresi, Müslüman ve müttefik Döngenlerin hıyaneti ve nihayet kanlı mücadelesi ile daha kendini tanıtamadan yıkıldı. Çin'in 36' 'ncı Generallik unvanı ile hareket eden bu cahil yağmacılar bir taraftan Çin'e ve son hareketleri ile Rusya ve Urumçi kızıl kuvvetine hizmet etmiş oldu.

Söz konusu rapora göre, o günlerde Çin on sekiz eyaletten oluşuyordu ve bunlardan biri de Doğu Türkistan'dı. Çin'de 1911 yılından sonra kurulan Cumhuriyet idaresi döneminde Doğu Türkistan'da yapılması lazım gelen birçok ıslahat olmasına rağmen iç isyanlar ve diğer dâhili sebepler yüzünden bölge kaderine terk edilmiş, pek iptidaî olan Çin idaresi düzelmemiş, bu suretle eski dönemde yüzü gülmeyen Türkistan, Cumhuriyet devrinde de istediği noktaya gelememiş̧ir. Raporda en dikkat çekici unsurlardan biri de Doğu Türkistan'ın yönetimiyle ilgili yapılan değerlendirmedir. Burada verilen bilgilere göre, Doğu Türkistan Genel Valisi merkezden bu bölgeyi satın alırdı. Merkeze ödediği parayı çıkarmak isteyen bu valiler kârlı çıkmak için memleketi adeta haraca bağlar ve istediği şekilde hüküm sürer ve mezalim uygulardı. 
Raporda verilen bilgilere bakılırsa, önceden Doğu Türkistan'da Urumçi'de Rusya'nın bir başkonsolosluğu, İngilizlerin ise Kaşgar bölgesinde bir başkonsolosu ve muhtelif merkezlerde Aksakal adı verilen ajanları vardı. İngilizler bu ajanlar vasıtasıyla komşu Afganistan içlerine kadar sokulmuş ve adeta orada serbestçe at koşturur vaziyete gelmişlerdi (BCA. 490.1.0/1197.194.1).

\section{Muhacirlerin Durumu}

Söz konusu raporda en fazla üzerinde durulan meselelerden biri de Doğu Türkistan'dan dışarıya yapılan göçler ve bu suretle ortaya çıkan muhacirlerin sorunlarıydı. Mecdettin Bey’e göre, 1917 yılındaki Bolşevik İhtilalinden sonra Türkistan'da Komünizm rejiminin uygulanmaya çalışılması nedeniyle on binlerce Türk, bin bir felâkete maruz kalarak dışarıya göç etmiş, yirmi iki yıldır bazen hızlı bazen yavaş devam eden bu göç dalgasının ardı arkası kesilmemiş, 1932 yılına gelindiğinde Doğu Türkistan'dan on binlerce Türk, Pamir, Karakurum yolu ile Hindistan ve Afganistan'a iltica etmişti. Raporda verilen bilgilere bakılırsa muhacirlerle ilgili asıl endişe edilmesi gereken durum onların çektikleri ekonomik zorluklar değil milli kimliklerini kaybetme tehlikeleriydi. Zira gereği gibi millî ve vatanî terbiye görmemiş bu zavallı Türk muhacirlerinin Hint ve Arap muhitlerinde maruz kaldıkları korkunç akıbet milli bir faciaya neden olmuş, bu muhitlerde sefil ve perişan kalan Türk gençliği şimdi öz dilini bile unutmuş, birçok muhacir çocukları ekseriyetle Türkçe konuşamaz hale gelmişlerdir. Mahallî mekteplere devam edenler ise büsbütün benliğini kaybetmişti (BCA. 490.1.0/1197.194.1).

Doğu Türkistan'dan Çin'e iltica edenlerin durumu ise daha farklıydı. Sayıları bin beş yüz- iki bin civarında bulunan bu Türkler fazla ilerlemeden Türkistan’a sınır olan Kansu, Sucu gibi muhitlerde kalmışlardı. Bir de merkeze kadar Şanghay ve Tianjin gibi ticari merkezlere gidip yerleşenler vardı ve bunların çoğu eskiden de bu bölgelerle ticari faaliyet gerçekleştiren kişilerdi. Bunlardan bir kısmı merkezde devlet şurası, planlama, eyalet teftiş heyeti ve saire azalıklarına tayin edilerek birdenbire Çin memuru oluvermişlerdi (BCA. 490.1.0/1197.194.1).

Raporda verilen bilgilere göre Doğu Türkistan direkt olarak Çin hâkimiyeti altında iken onların nüfuz ve tesiri altında olanlardan ibaret bir zümre, millî harekât müddetince zaten Çinlilerle ve bilâhare Çin maskeli komünistlerle ortak hareket etmişti. Mesela bu kişilerden biri de yakın zamanda Ankara’ya 
gelerek Çin propagandası yapan ve saf Türk seciyesine yakışmayan bir hareket ile bütün Türkistanlıları mahcup bırakan İsa Yusuf isminde birisi idi. Raporda İsa Yusuf Bey'in faaliyetleri ile ilgili şu ifadeler kullanılmıştır:

Uzun müddet Taşkent'teki Çin Konsolosluğunda tercüman olarak bulunan İsa, zekâsını menfi sahada kullanan, millî harekâtı içeriden zedeleyen bir kişiydi. Zahiren makul bulunan fikirleri ile Türklüğe değil Çin emeline, Türk ülkesinin esaretine hizmet eden bu kişiler bin bir meşakkatle Türkiye’ye gelen Doğu Türkistanlı çocuklardan birkaçını kandırıp Çin’e götürmüş, bu çocuklar da daha sonra Şanghay'a kaçmıştı. Daha önceden Hindistan'dan, Çin'e götürülen çocukların Türk ve İslâm terbiyesine uymayan ve tahsilden ziyade propagandadan ibaret bulunan komünizm akideleri ile karşılaşmalarına sebep olan kişi İsa Yusuf idi. (BCA. 490.1.0/1197.194.1)

Mecdettin Bey'in burada yer verdiği görüşlere bakıldığında Doğu Türkistan'ın bağımsızlık mücadelesinde yer alan İsa Yusuf Bey’e (Alptekin) bazı eleştiriler getirdiği müşahede edilmiştir. Zira bu dönemde Çin ile iş birliği yapma taraftarı olan (Kul 2015: 146) Alptekin'in bu tavrı sanırız Mecdettin Bey tarafından ihanet olarak görülmüştür.

Raporda muhacirlerle ilgili bilgiler verilmeye devam edilmiş ve Çin'e gidenler arasında az çok vatansever terbiye almış ve bunun neticesi olarak milli hareketlerde bulunanların da olduğu ifade edilmiştir. Bu kişilere Mesut Sabri ve Abdülkadir Mansur Beyler örnek olarak gösterilmiştir. Bunlar Balkan Harbinden önce Türkiye’ye gelmiştir, Mesut Sabri Mülkî Tibbiyeye, Abdülkadir Bey ise Beyrut Kolejine girmiş, mekteplerini bitiremeden memlekete dönmüşlerdi. Mesut, Gulca’da millî harekâta tıbbi yardımlarda bulunmak suretiyle iştirak etmiş ve 1934 başında Yenihisar'da General Muhiti'den ayrılarak Nankin'de tahsilde bulunan oğlunun yanına gitmiş, Abdülkadir Mansur ise Ruslar kendisinden şüphelendiği için Doğu Türkistan hudutları dışına çıkmasına yardım edilmiştir (BCA. 490.1.0/1197.194.1).

Doğu Türkistan'dan dış memleketlere göç eden Türklerin ele alındığı raporun bu bölümünde, muhacirlerin memleketlerine dönme isteklerinin hiç bitmediği, gittikleri memleketlerde iş güç sahibi olanların dahi o işi geçici olarak gördükleri gerek Afganistan gerekse İran ve Hindistan'da yurtlarına dönme imkânını bulduğu anda her işi yüz üstü bırakmağa hazır halde bulunan binlerce Türkistanlı muhacirlerin olduğu belirtilmiştir. Bu manevi bağın kopma- 
masının temel nedeni, farklı ülkelerde bulunan muhacirlere yönelik yürütülen sosyal ve kültürel hareketlerdi. Zira muhacirler için kurulan cemiyetler, çıkarılan gazete ve mecmualar vasıtasıyla onların anavatana bağlılık hisleri her daim canlı tutulmaya çalışılmıştır (BCA. 490.1.0/1197.194.1).

Mecdettin Bey'in kaleme aldığı söz konusu raporda Türkistan'dan dış memleketlere göç etmek zorunda kalan muhacirlere yönelik sürdürülen faaliyetlerle ilgili önemli tespitler yapılmış, bu kısımda şu ifadelere yer verilmiştir:

İmkân buldukları ve şeraiti müsait bulunan yerlerde müşterek cemiyetlerle az çok içtimaî hareketlere de başlamışlar ve matbuatın da mühim bir ihtiyaç olduğunu idrak ettiklerinden yoksulluklarına rağmen neşriyata girişmişlerdir. İstanbul'da 1927 senesinde teşekkül eden, Türkistan Türk Gençler Birliği ile Hindistan'daki Türkistan Muhacirler Birliği, Mısır ve Suriye'deki muhtelif birlikler muhacirler arasında içtimaî hareketin inkişafına canlı misallerdir. Yine İstanbul'da 1927'de intişara başlayan Yeni Türkistan ile 1929'da Berlin'de neşredilen Yaş Türkistan mecmuaları Türkistan muhacir hayatının ilk Türkçe millî neşriyatı ve mürevvic-i efkârı idi. 1934'de Hindistan'daki birlik Sada-i Muhacirin namile Türkçe, Farsça ve Ordu'ca/Urdu'ca üç dilde mecmua çıkarmağa başladı. 1936'da maddî imkânsızlıktan faaliyetini tatil eden bu neşriyat yerine 1937 sonunda Tercüman çıktı. Türkistan muhacirlerinin bu neşriyatı sade bir ülkeye münhasır kalmamış kendi dertleri meyanında Türk dünyasından da haberler derc ederek hususen bugünkü Türkiye’yi muhacirlere tanıtmağa çalışmış, her iki Türkistan'ın müşterek fikir ve hareket organı olmuşlardır. (BCA. 490.1.0/1197.194.1)

Raporun son bölümünde muhacirlerin bilinçlendirilmesi hususunda neler yapılması lazım geldiği üzerinde durulmuştur. Buna göre muhacirlerin bulunduğu yabancı muhitlerde eriyip gitmemesini temin, onların tavır ve hareketine millî renk, faaliyetlerine millî istikamet verilmesi gerekliydi ve bu da ancak vazifesine layıkıyla hazırlanmış kadrolar yetiştirmek suretiyle mümkün olabilirdi. Muhacirlerin yerleştikleri muhitlere muallimler yollamak veya muhacir çocuklarını Türkiye'ye getirterek burada eğitip, hazırlayıp vazifesi başına yollamak gerekirdi. Bu tür faaliyetlerden verimli bir netice elde edebilmek için de muhacir çocukları ile ilgilenilmesi gerekirdi. Zira onların yaşı ile bilgi seviyesi arasındaki açıklığı mümkün olduğu kadar kısa müddette doldurup uygun bir sınıfa devam edebilmesini temin edecek tedbirlerin de alınmış olması lâzımdı. Bu tedbirler sayesinde pek de büyük olmayan bir fedakârlıkla nispeten kısa 
bir müddet içinde vazifesine bağlı, milli bilince sahip bir kadro hazırlayıp, yetiştirmek mümkün olabilirdi (BCA. 490.1.0/1197.194.1).

\section{Doğu Türkistan'la Kültürel Münasebetler ve Yeni Türk Harflerinin Gön- derilmesi Hususu}

Doğu Türkistan'ın ve buradan dışarıya göç eden soydaşların durumuyla ilgili Mecdettin Delil'in Türkiye Cumhuriyeti Başvekâletine sunduğu yukarıda zikredilen raporu yetkililer tarafından incelenmiş ve gelişen süreçte Doğu Türkistan'ın kültürel durumu masaya yatırılmıştır. Zira Cumhuriyetin ilk yıllarında Türkiye'de yaşanan bazı gelişmeler her iki toplum arasında ister istemez kültürel bir kopukluk meydana getirmişti. Bunlardan en önemlisi şüphesiz harf devrimiydi. 1928 yılında yaşanan bu köklü değişim dünyanın değişik bölgelerindeki Türklerle temas halinde bulunan Türkiye Cumhuriyeti Devleti için yeni bazı gereksinimleri ortaya çıkarmış, gerek Avrupa'da ve gerekse de Asya coğrafyasında yaşayan soydaşlara bu yeni harflerin tanıtımı gerekli hale gelmişti. Zira ortak bir kültürel taban oluşturulmak isteniyorsa bu husus asla ihmal edilemezdi. Bu kapsamda harekete geçen Türk Hükümeti, Mecdettin Bey'in raporunu da dikkate alarak Doğu Türkistan'da yaşayan Türklere yeni Türk harflerinin tanıtılması için girişimlere başlamışıı. $\mathrm{Bu}$ hususta Başvekâlet makamına gönderilen bir raporda, Çin Türkistan’nnda ve Çin'in diğer bölgelerinde yaşayan Türkler arasında yeni harflerin neşri ve Türkistan'dan Türkiye'ye tahsil için birkaç talebe getirilmesinin temini hakkında Türkiye'nin Chungking Elçiliğinden alınan yazının ekte gönderildiği ifade edilmiştir (BCA. 030.10/257.728.16). Türkiye'nin Chungking Elçiliğinden gönderilen söz konusu raporun ek kısmında ise ilk olarak burada yaşayan Türklerin o günkü kültürel vaziyetleri hakkında bilgiler verilmiştir. Burada yer alan ifadelere bakılırsa Çin’ in Türkistan bölgesi merkezden gönderilen bir vali ile yönetiliyordu. Fakat buranın merkezle olan bağları gayet zayıf bir durumdaydı. Buna karşın bölgede hâkimiyet kurmak isteyen Sovyetler Birliği'nin Türkistan'da bazı gençleri ülkesine getirterek komünist terbiyesi ile yetiştirdiği daha sonra Türkistan'a göndererek münevver ve milliyetçi fikirleri ortadan kaldırmaya çalıştığı bu nedenle Türkistan'dan Hindistan’a doğru büyük bir göç hareketi yaşandığı hatta Türkistan muhacirlerinin Hindistan'ın Delhi şehrinde kayda değer bir sayıya ulaştıkları ve burada bazen Türkçe de neşredilen Tercüman-ı Delhi Gazetesi'nin çıkarıldığı ifade edilmiştir. Raporda Çin’in diğer bölgelerinde yaşayan Türklerle ilgili çok fazla bilgi sahibi olunamadığı 
belirtilmiş, ayrıca Çin'de herhangi bir Türk okulunun olup olmadığının tespit edilemediği, sadece Chungking yakınında bir yerde Hudut Mektebi adı verilen ve öğrencilerinin çoğunluğunu Moğol, Tibetli ve Türkistanlıların oluşturduğu resmî bir mektebin olduğu, burada öğrenim gören 10 öğrencinin bulunduğu ve okuldaki Türkler için derslerin Türkçe okutulduğu ifade edilmiştir (BCA. 030.10/257.728.16).

Elçilikten gönderilen rapora göre gerek Hudut Mektebìnde gerek hususî tedrisatta Türkçe dersleri eski harflerle veriliyordu. Zira Hudut Mektebinnde görevli Türkçe öğretmeni Mesud Sabri Bey Yurt isminde eski harflerle neşredilmiş, aylık ve yalnız 120 nüsha basılan bir mecmuayı ders kitabı olarak okutuyordu. Elçilikçe yapılan tahkikatta Yurt Mecmuası'nın bir kısmının Türkistan’a bir kısmının Hindistan'a bir kısmının da Türkiye’ye gönderildiği anlaşılmıştır.

Türkiye’nin Chungking Büyükelçiliğinden Ankara’ya gönderilen raporun devamında verilen bilgilere bakılırsa Çin'deki Türkler arasında henüz yeni alfabe kullanılmıyordu. Fakat bu durum eskiye bağlılık veya bağnazlıktan ziyade bu meseleyle ilgilenilmemesinden ileri geliyordu. Hâlihazırda eski harflerle tedrisat yapacak muallim, kitap vs. bulunamadığı halde yeni harflerle bu işin nasıl yapılacağı büyük bir soru işaretiydi. Söz konusu rapora göre yeni harflerle tedrisat işine önem verilmezse buradaki soydaşlar büsbütün tahsil isteğini kaybedecek veyahut da tahsil ihtiyacını milli duygulara gayri müsait vesait ve çarelerle temine çalışacaktı. Bu endişelerle olacak ki Chungking Büyükelçiliği tarafından, Yurt Mecmuasi'nı çıkaran Mesud Sabri Bey'e mecmuasını yeni harflere çevirmesi ve tedrisatını yeni harflerle yapması teklif edilmiştir. Kendisine elçilikçe alfabe temin edileceği ve gerekli kitapların Türkiye'den isteneceği de ayrıca ifade edilmiştir (BCA. 030.10/257.728.16).

Chungking Büyükelçiliği yeni Türk harflerinin Çin'de yaşayan soydaşlarımıza ulaştırılması için harekete geçmiş ve bu konuda nabız yoklamaya başlamıştır. Bu kapsamda Çin Dış İşleri şerefine verilen bir ziyafette davetliler arasında bulunan Çin Millî Terbiye Nazırına konu açılmıştır. Fakat nazır, meseleyi pek anlamamış biraz da tehlikeli görmüş olacak ki bu gibi işlerle -yani ekalliyetlerle ilgili- Çin Halk Fırkasının meşgul olduğu cevabını vermiştir. Çinli bakanın endişelerini gidermeye çalışan Türk Büyükelçisi bunun bir ekalliyet meselesi olmadığını sadece Türkiye'de tahakkuk eden bir inkılâbın Çin vatandaşlğ̆ında bulunan Türkler tarafından kabul edilmesini sağlamak olduğunu ifade etmiştir. Chungking Büyükelçisi daha sonra bu mesele ile ilgili olarak 
kendisinin bizzat ilgileneceğini, Çin Hükümeti'nin bu işe karşı çıkacağını zannetmediğini ve bunun için sebep de olmadığını, vakit kaybetmeden resmi başvuruların yapılması gerektiğini ifade etmiştir. Türkiye'nin Chungking Büyükelçiliğìnden gönderilen yazının son kısmında birkaç Türkistanlı öğrencinin Türkiye'de tahsillerinin temini hakkında CHP Genel Sekreteri Ahmet Fikri Tüzer'e bilgi verildiği ve bu meselenin onun tarafından kabul edildiği, Parti'nin de onay vermesinin ardından harekete geçileceği ifade edilmiştir (BCA. 030.10/257.728.16).

Bu rapora benzer olmakla birlikte, 30 Aralık 1940 tarihinde Türkiye'nin Chungking Büyükelçiliğinden CHP Genel Sekreterliğine bir yazı gönderilmiştir. Yazıda Türk Hükümeti'nden beklentiler şu şekilde sıralanmıştır:

Esasen Çin'de ikamet eden veya Şarki Türkistan'dan Çin'e iltica ederek orada barınan ırkdaşlarımızın milli karakterlerini muhafaza etmek ve kültür sahasındaki ihtiyaçlarına mümkün mertebe cevap verebilmek maksadıyla CHP'den de icap eden yardımın ve bilhassa Türk harflerinin oralara neşir ve tamimi için iktiza eden muavenetin yapılması istenmekte olduğundan, başta Türk alfabesi olmak üzere kıraat, Türk tarihine, milli menkıbeye müteallik ve o muhite elverişli olmak kayıt ve şartıyla seçilecek eserlerin isimlerini bildiren bir listenin tanzimiyle gönderilmesine müsaadelerinizi sonsuz saygılarımla rica ederim.

Elçilikten gelen yukarıdaki yazının ardından Ankara'daki yetkililerce harekete geçilmiş ve konu CHP Erzurum Milletvekili ve Genel Sekreter F. Tuzer tarafından takip edilmeye başlanmıştır. F. Tuzer tarafından kaleme alınan bir yazıda Chungking Elçiliği'nden yüksek vekâlete gönderilen mektupların ehemmiyetle tetkik ve mütalaa edildiği ve Doğu Türkistan'da ve Çin'de yaşayan ırkdaşlara azami alakanın gösterildiği ifade edilmiştir. Genel Sekreter F. Tuzer’ in ifade ettiği âzamî alâka gösterilecektir sözü kısa zaman sonra somut bir hale gelmiş ve o bölgelerden Türkiye'ye öğrenci getirtilerek bir anlamda Doğu Türkistan ile Türkiye arasında kültürel bir köprü kurulmuştur. Söz konusu yazıda verilen bilgilere göre, Çin'den gelip Türkiye'de okuyan talebelerden on beşi parti himayesinde okutulmuştu ve bunlardan ikisi Çin Türklerinden, üçü Kaşgarlı ve diğer ikisi de Mançokolu idi (BCA. 490.01/1197.194.1).

Chungking Büyükelçiliği tarafından Ankara’ya gönderilen bu iki rapordan kısa bir süre sonra aynı yönde bir başka rapor daha kaleme alınmıştır. Bu raporun üst yazısında daha önce yeni harflerin Çin'deki ırkdaşlara ulaştırılması meselesi hakkında bir yazı gönderildiği şimdi ise buradaki soydaşların kitap 
ihtiyaçları hakkında yeni bir rapor tanzim edildiği ve takdirin Maarif Vekâleti ve CHP Genel Sekreterliğine ait olduğu belirtilmiştir. Söz konusu rapor şu şekilde başlamaktadır:

Çin'de camia hayatları... maruz kalan ve ötede beride küçük kitleler veya büsbütün dağınık bir halde ve pek müşkül şartlar dâhilinde yaşayan ırkdaşlarımız evlatlarının millî ve manevî terbiyeleri için elçiliğe müracaatla kitap istemektedirler. Her cihetle alâka ve sahabete şayan hemen hepsi memleketimize hicret için firsat ve imkâna muntazır olan ve mektepsiz kitapsız ve muallimsiz bir vaziyette kalan bu ırkdaşlarımızın kabil olduğu kadar manevî fizyonomilerinin kurtarılmasına ve ırkî hüviyetlerinin korunmasına karışmak gerçekten bir insani vecibe teşkil etmektedir. Bu yolda gösterilecek herhangi bir alâkanın müstakbel vatandaşlara masrufiyeti nazar-1 dikkate alınırsa bu vecibe daha büyük bir ehemmiyet iktisap etmektedir. Bu sebeple Çin'deki ırkdaşlarımızın kitap ihtiyaçları hakkında Maarif Vekâletinin, parti kâtibi umumiliğinin Türk Dili ve Türk Tarihi Kurumlarının vesaire millî teşekküllerimizin lütufkâr dikkat nazarlarının celbine müsaade-i devletlerini rica ederim.

Raporda da görüldüğü üzere Çin'de bulunan Türk vatandaşları, Türk Büyükelçiliğine başvurarak Türkçe kitap talep etmişlerdi. Raporda en dikkat çekici ifadelerden biri de buradaki Türklerin oldukça zor durumda oldukları ve şartlar uygun olduğu takdirde Türkiye'ye gelmek için firsat kolladıklarıydı. Raporun ilerleyen bölümlerinde kitap basımı meselesi ile bilgiler verilmiştir. Burada verilen bilgilere bakılırsa Çin'de kitap bastırmak ve bunu dağıtmak büyük bir masraf gerektirmiyordu. Hatta basılacak kitapların tıpkı asılları gibi çıktığı, Avrupa ülkelerine kıyasla fiyatlarının neredeyse dörtte biri oranında ucuza mal olduğu ifade edilmiştir. Özetle buradaki soydaşların kitap ihtiyacının küçük bir meblağ ile tamamen karşılanabileceği öne sürülmüş, bu faaliyetin Çin'de herhangi bir engelle karşılaşmayacağı da ayrıca belirtilmiştir (BCA. 030.10/257.728.17).

Ankaràya gelen bu rapor ve istekler zamanla yetkililerce de uygun bulunmuş olacak ki Çin'de yaşayan soydaşlara yardım eli uzatılmıştır. Bilhassa Türk Dil Kurumu tarafından bazı yayınlar seçilerek Çin'e gönderilmiştir. Konuyla ilgili olarak kaleme alınan bir yazıda, Çin Elçiliğinden Hariciye Vekâleti'ne gelen yazıda bölgeye gönderilen yayınların çok makbule geçtiği ifade edilmiş aynı şekilde yayın gönderilmeye devam edilmesi gerektiği temenni edilmiştir (BCA 490.1.0/1197.194.1). 


\section{Sonuç}

1930’lara kadar iç politik gelişmeler ve Lozan'dan arda kalan meselelerle uğraşan Türkiye Cumhuriyeti, anılan tarihten itibaren daha aktif bir dış politika takip etmeye başlamıştır. Türk Hükümeti 1930 sonrası dünyada yaşanan gelişmeler sonucunda dış politika parametrelerini değiştirmek zorunda kalmış, bu kapsamda Sovyetler Birliği ile iyi ilişkiler kurulmuşken buna ek olarak Batılı devletlerle de yakın temas içine girilmiştir. Bu değişikliklere ilave olarak yeni rejimin farklı coğrafyalarda tanıtılmasına da gayret edilmiştir. Özellikle Türk dünyasına ilgi gösteren Türkiye, bu bölgede yaşayan soydaşların durumları hakkında bilgi sahibi olmaya çalışış ve Doğu Türkistan'da yaşayan Türklerle kültürel münasebetleri geliştirme çabası içine girmiştir.

Bu kapsamda Türkistan Türk Gençler Birliği Derneği kurucularından Dr. Mecdettin Delil tarafından, Türk makamlarına gönderilmek üzere oldukça uzun ve kapsamlı bir rapor kaleme alınmış ve buradaki Türklerin ekonomik, sosyal ve kültürel sorunları hakkında bilgiler verilmiştir. Raporu yazmadan çok kısa bir süre önce Doğu Türkistan'da bağımsılık hareketlerini organize etmek için bulunan Mecdettin Bey'in tespitleri bölgenin son halini en iyi bilen kişilerden biri olması nedeniyle dikkate değer bir nitelik taşımaktadır.

Mecdettin Delil'in kaleme aldığg raporun içeriğine genel olarak bakıldığında, Türkistan'ın esaret altından kurtarılması, hür ve bağımsız hale gelmesi, bu uğurda uzaktan da olsa neler yapılması gerektiği, Türkiye Cumhuriyeti ile bölge halkı arasında manevi bağlantının tesisi gibi meseleler üzerinde durulduğu görülmüştür. Mecdettin Bey'in en fazla üzerinde yoğunlaştığı konu Doğu Türkistan’ın bağımsızlık mücadelesine destek vermeyen Döngenlerin vaziyetiydi. Artık gittikçe Çinlileşen bu topluluğun bölgedeki Türklere her türlü hıyaneti yaptığını ifade eden Delil'e göre, eğer gerekli tedbirler alınmazsa ileride birçok vatansever Türk'ün, tıpkı Döngenler gibi Çin etkisi alına girme tehlikesi vardı. Mecdettin Bey'e göre bu tehlikeyi bertaraf etmek için Doğu Türkistan'da bulunan soydaşlarla daha fazla ilgilenilmesi gerekiyordu. Zira Türkiye, Doğu Türkistan'daki Türklerle irtibatını koparmamalı, kültürel ilişkilerini geliştirmeliydi. Daha somut bir ifadeyle; bağımsızlığına düşkün, milliyetçi hislerle dolu nesiller yetiştirmek için Türkiye ile iş birliği içine girilmeli ve bu noktada en önemli sorun olan alfabe farklıllı̆̆ meselesi çözüme kavuşturularak bölgeye yeni Türk harfleri gönderilmeliydi. Dönemin Türk Hükümeti Mecdettin Bey’ in raporunda ifade ettiği bu hususları dikkate alarak kısa süre içinde ça- 
lışmalara başlamış ve Chungking Büyükelçiliği vasıtasıyla Doğu Türkistan’a yeni Türk harfleri ve bu harflerle basılmış bazı eserler gönderilmiştir.

Mecdettin Delil'in raporunda en fazla muhacirlerin üzerinde durulmuştur. Ona göre Doğu Türkistan muhacirleri için asıl tehlike geçim sıkıntısı değil özünü, aslını muhafaza edememe tehlikesiydi. Bu tehlikenin ortadan kaldırılması için koordineli şekilde hareket edilmeli, basın-yayın faaliyetlerine ağırlık verilmeli ve milliyetçi damarı sağlam bir nesil yetiştirilmeliydi.

Mecdettin Delil tarafından kaleme alınan raporun ilginç bir özelliği de 1940 yılında yani İkinci Dünya Savaşı döneminde hazırlanmasıdır. Bu tarihlerde Sovyetler Birliği ve Çin gibi Doğu Türkistan'la komşu ülkelerle henüz büyük bir problemi olmayan Türk Hükümeti, bu firsattan istifade ederek Mecdettin Bey’in raporunda belirttiği meseleler üzerinde durmuş ve talep ettiği hususları hayata geçirmek için gayret sarf etmiştir. Bu kapsamda Türk Dil Kurumu, Halkevleri gibi kurumların desteğiyle Doğu Türkistan'a kitap, defter, broşür gibi malzemeler ile yeni harfler gönderilmiş, ayrıca burada bulunan Türk çocuklarından bazıları Türkiye'ye getirtilerek Türk okullarında okumaları sağlanmıştır. Getirtilen Türk çocukları Millî Eğitim Bakanlığı ve CHP’nin organizasyonuyla yetenek ve isteklerine göre ülke içindeki okullara dağıtılmıştır. Türk uyruklu öğrencilerin Türkiye'ye getirilmesi ve genel durumları başka bir çalışmamızın konusunu teşkil etmektedir.

Sonuç olarak Cumhuriyetin ilk yıllarında Türkiye ile Doğu Türkistan arasında gerçekleşen bu faaliyetlerle soy ve tarih birliğinin yanında ortak bir kültür ile gelecek inşa etme gayreti içine girilmiştir.

\section{Açıklamalar}

1. Binlerce yıllık geçmişi ile dünyanın en önemli medeniyetlerine ev sahipliği yapmış olan Doğu Türkistan kuzeyde Rusya, batıda Kazakistan, Kırgızistan ve Tacikistan, güneyde Afganistan, Pakistan, Hindistan ve Tibet, doğuda Çin ve Moğolistan’la ortak sınırlara sahiptir. 1877 yılındaki Çin-Mançu istilasından sonra "Yeni Toprak" anlamına gelen "Şin Jiang” olarak adı değiştirilmiş, 1 Ekim 1955 tarihinde kurulan “Şin Jiang Uygur Otonom Bölgesi” adıyla da bugünkü idari statüsü kazandırılmıştır (Demirağ 2014: 230).

2. Mustafa Çokayoğlu (1890-1941): Taşkent'de doğdu. İlk ve orta tahsilini burada yaptıktan sonra üniversite öğrenimini Petersburg Hukuk Fakültesi'nde tamamladı. 1917 yılında Türkistan'a dönüp Taşkent'de Türkistan Milli Merkezi Şûrasıının başkanlığına seçildi. 1917 yılında Kerenski Hükümetinin 
düşüp Bolşeviklerin iktidara gelişiyle Türkistanlılar, Hokand Muhtariyeti'ni ilan ettiler. Mustafa Çokayoğlu muhtariyetin cumhurbaşkanlığına seçildi. Fakat Bolşeviklerin 1918'de muhtariyeti dağıtmasıyla Mustafa Çokayoğlu da birçok Türkistanlı gibi Avrupa'ya göç etti. Uzun süre Paris ve Berlin'de yaşayan Çokayoğlu, 1927'de Yeni Türkistan’n, 1929،da Yaş Türkistan’ı çıkarılmasında görev aldı. 1941 yılında Berlin'de vefat etti. Mustafa Çokayoğlu ile ilgili daha ayrıntılı bilgi için bkz. (Abdulvahap Kara (2002). Türkistan Ateşi: Mustafa Çokay. İstanbul. 278-279).

3 Mecdettin Delil, 1942 yılında Mustafa Çokay Albümü adlı eseri hazırlamış ve basmıştır. (Mecdettin Delil (1942). Türkistan Türklerinin Büyük Milliyetçi Yurtseverlerinden Mustafa Çokay Albümü. İstanbul).

$4 \quad 1927$ 'nin Haziran'ında ilk sayısı yayınlanan derginin adının Yeni Türkistan olarak konulmasındaki amaç, Rusya'da yasaklanan Türkistan adının tüm Orta Asya’yı kapsayan bir isim olmasıydı. Yeni kelimesi ile de milli bağımsızlık sonrası kurulacak olan Türkistan’ın kastedilmesiydi. Derginin imtiyaz sahibi ilk sayısından 28. sayıya kadar Osman Kocaoğlu, sorumlu müdürü ise Mehmet Kazım Beydi. 28. sayıda derginin imtiyaz sahibi Nasir Hekimzade'dir. 29. sayıdan (son sayı olan) 39 sayıya kadar ise hem imtiyaz sahibi hem de sorumlu müdür Mecdettin (Delil) Ahmet Bey'dir. (Rasim Bayraktar (2013). "Türkistanlı Aydınlarımızın Siyasi ve Yayın Mücadelesi: Mustafa Çokayoğlu ve Etrafındakiler”. Atatürk Üniversitesi İlahiyat Fakültesi Dergisi 39: 319).

5 Çoğunlukla boyacılıkta kullanılan, petrol türevlerinden bir çeşit mineral yağ, neft yağ $\mathrm{da}$ denilir.

6 Döngen kelimesi Çincesde Tung-kan, Rus ve Batı kaynaklarında Tungan ve Dungan şeklinde geçer. Doğu Türkistan Türkleri bütün Çin Müslümanlarına bu adı verseler de bunlar bugün daha çok Hui -hui veya Hui-tse adıyla anılmaktadır. Sünni Müslüman olan Döngenler daha ziyade Hanefi mezhebine mensuptur. Döngenler’in kültür yapılarında hala Çin geleneklerinin etkisi sürmekte olup günlük hayatları Çinlilerden farklı değildir. (Cemil Hee Soo (1994). "Döngenler". DİA. C. 9. 217-218).

7 Türk Hükümeti bu süreçte Doğu Türkistan'da aylık yayınlanan İslam Gençliği Mecmuası'nı Ankara'ya getirtmiş ve Matbuat Umum Müdürlüğüne tercüme ettirerek inceletmiştir. Tercümenin kenarına yazılan bir notta mecmuanın ilk ve son sahifelerinin Çince ikinci kısmının Arapça, üçüncü kısmının ise Türkistan Çini diline yazıldığı ifade edilmiştir (BCA, 030.10/257.728.19). 


\section{Kaynaklar}

\section{Arşiv Kaynakları}

Başbakanlık Cumhuriyet Arşivi, BCA 490.1.0/1197.194.1

BCA 030.10/257.728.16

BCA 490.01/1197.194.1

BCA, 030.10/257.728.19

BCA 030.10/257.728.17

\section{Araştırma Eserler}

Anat, Hacı Yakup (2005). Doğu Türkistan'da Milliyetçilik Hareketleri. Ankara: Özkan Matbaacilik.

Andican, Ahat (2003). Cedidizm'den Bağımsızlı̆̆a Hariçte Türkistan Mücadelesi. İstanbul: Emre Yay.

Bayraktar, Rasim (2013). "Türkistanlı Aydınlarımızın Siyasi ve Yayın Mücadelesi: Mustafa Çokayoğlu ve Etrafındakiler”. Atatürk Üniversitesi İlahiyat Fakültesi Dergisi 39: 307-330.

Çınar, Orhan (2012). "Yeni Türkistan Dergisi”. Akademik Bakı̧ Dergisi (30): 1-13. Delil, Mecdettin (1942). Türkistan Türklerinin Büyük Milliyetçi ve Yurtseverlerinden Mustafa Çokay Albümü. İstanbul: Numune Matbaası.

Demirağ, Yelda (2014). “1755-1949 Yılları Arasında Doğu Türkistan”. Uluslararası Uygur Araştırmaları Dergisi (3): 229-245.

Emet, Erkin (2002). “Doğu Türkistan Özerk Cumhuriyeti”. Türkler. C. 20. Ankara: Yeni Türkiye Yay. 276-281.

Hee Soo, Cemil (1994). "Döngenler”. İslam Ansiklopedisi. C. 9. Ankara: TDV Yay. 517-518.

Gömeç, Saadettin (1998). Uygur Türkleri Tarihi ve Kültürü. Ankara: Akçay Yay.

Kafesoğlu, İbrahim (1993). Türk Milli Kültürü. İstanbul: Boğaziçi Yay.

Kul, Ömer (2015). "Tarihte Düzenlenen İlk Doğu Türkistan Kurultayı: Hicaz Kurultayı (1-5 Eylül 1954)". Türkiyat Mecmuası 25.

Kara, Abdulvahap (2002). Türkistan Ateşi: Mustafa Çokay. İstanbul: DA Yay.

Saray, Mehmet (1995). Atatürk ve Türk Dünyası. Ankara: TTK Yay.

Taşağıl, Ahmet (2012). “Türkistan”. İslam Ansiklopedisi. Ankara: TDV Yay. 556560.

Türkler, Erkin (2015). “Sincan: Çin'in Başarılı Algı Operasyonu”. Türk Yurdu 104 (331): 27-28. 
Ek.1. Türkistan’a Gönderilecek Yeni Türk Harfleri Hakkında

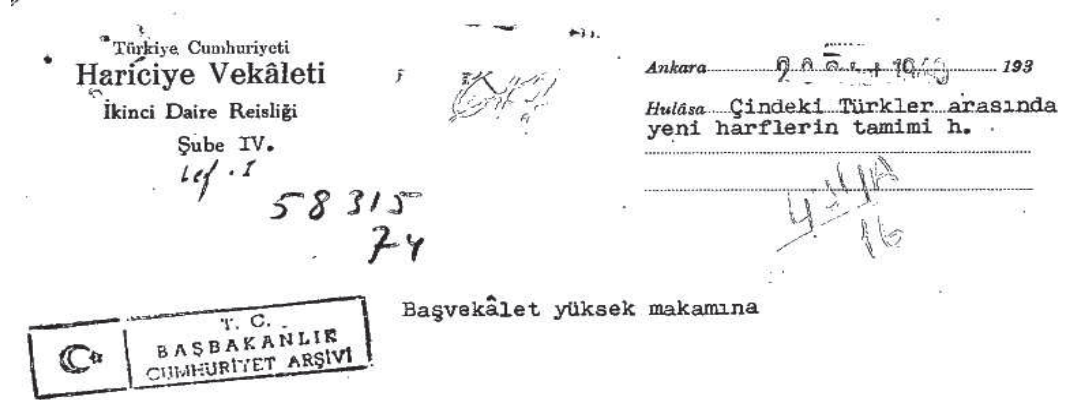

Çin Turkistanında ve Çin'in diğer taraflarında yaşayan Türkler arasında yeni harflerimizin neşrü tamimi ve Tükistandan yurdumuza tahsil için bir kaç talebe getirilmesinin temini hakkinda Chungking Elçiliğimizden allnan 29.I. 1940 tarihli ve $63 / 14$ sayilı yazının bir örně̌inin, ilişik olarak takdim kılındığını ve keyfiyețin Maarif Vekâletile Cumhuriyet Halk Partisi Genel Sekreterliğine de bildirilmis oldugunu derin saygılarımla arzederim.

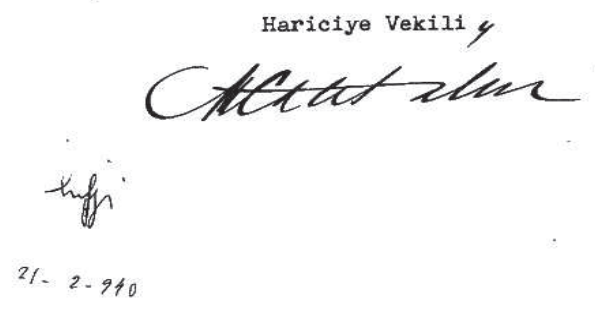

\begin{tabular}{|l|l|l|l|l|}
\hline 030 & 10 & & & (25rites \\
\hline
\end{tabular}

Kaynak: Cumhurbaşkanlığı Devlet Arşivi: Fon Kodu: 303.10/Yer No: 257.728.16 


billig $\quad$ Başkaya, Arşiv Belgelerine Göre Cumhuriyetin İlk Yillannda Doğu Türkistan'inn Genel Durumu ve
Türkiye ile Kültürrel Münasebetler $\bullet$

Ek.2. Mecdettin Bey'in Raporunda Muhacirlerle İlgili Bir Bölüm

14.

Çine gidenler arasında az çok millf terbiyesi ve bu terbiye neticesı olarak bilvesita olsa da o der muhit ve geyri milsait şeraitte fikrf hareketlerde bulunanlar da yok degildir. Bu_cümleden Lesut Sabri re, pek cesaretlijolmesa da, Abdülkadir Kansurlarl zi:redebiliriz. Bunlaran ikisi de Belkan harbinden önce Türkiyeye gelmişler, hesut, Mülki Tıbbiyeye, Kadir Beyrut Kollejine Eirmişlerken mekteplerini ikmel etmeden memlekete dönmüşlerdir . Mesut Golcada mill1 harekâte tıbbf yerdımlarda bulunmak suretile iştirak etmiş ve 934 bideyetinden Yenihisarda Generel Luhitiden ayrllarak Nankin'de tahsilde bulunan 8 oflunun yenıne ö tmişti. Kadir kansurt" ise, kendisinden Rusler şüphelenerek
tolkip ederlerken, yine Muhiti terafından mahfi surette hudut hericine çlkması-
na yardım edilmiştir.

na yardlm edilmiştir. kaybetmemiştir. Huhaceret heyetınde o:dukçe iş cü̧ sahibi olenler bile b işe adetl murakks.t ve geçici nezarle bakerler. Yurde dönmek imkenını bulduğu anda her işi yüz üstü błrakmcogs amede bir hilde nulunan Türkistanlı muhecirlere gerek AfEan ve gerekse Lren ve Hindistendt çok restlenır. Bu hel muhecirlerin ber nerece ve hengi muhit tesiri eltind $\varepsilon$ o:ursa olsun yurde beflill I noktasınden umumf bir fikir birliłgini inteç ediyorse de muhacir kitlenin ilmf, 1çtimal re siyesf scinadi seviyece ferkl 1 re ekseriyetle bu hususlerde hazirliks1z o_mesı yüzünden bir çok noksinlikleri hele filf sehede bir verlik gösterememel Gibi hillere tesedüf o unmaktrdır. ((Işin yelnız dilekle değłl, dileğin

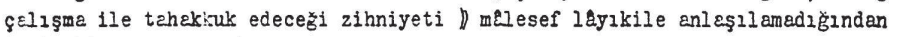
insiyakf mehiyette olsa da yurda dönmek kanaet ve fijrinden, bu fikir üzerin-

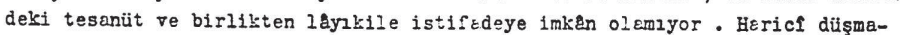
nın (Kus ve çinin) her $i$ 'i Türkisten için de eyni 0 :ması G. ve ̧. Türkistanl.

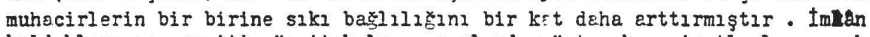
bulduklerı te şereiti müseit bulunan yerlerde müşterek cemiyetlerle az çok 1çtimeil hereketlere de başlomışler ve metbuetın de mühim bir ihtiyaç olduǧnu idrek ettiklerinden, yoksulluklerın rakmen, neşriykta Girişmişlerdir.

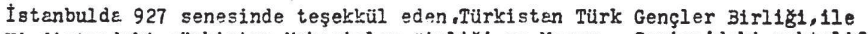
Hindistandaki " rürkisten Luhe cirler Sirliogl, ve Hasir, Suriye'deki muhtelif birltkler auh cirler erasınde ictimal hereketin inkişef ıne canlı misallerdir. Yino Istanbulde 927 de intiştre beşleyen ,Yeni Türkistan "1le 929 de Berlinde neşredilen. Yaş Türkistan. mecmuiları Türkistan muhicir heyatinın ilk Türkçe mil: I neşriyetz ve murevvici efkếr idi . .Yeni Türkisten 932 de kapatıldı . .Yes Türisistan.ise on sene muntazeman deven ederek son herp dolzyısile neşriyetinl muvalketen tetil etti . 934 de Hindistandaki birlik. Sedayi Huhccirin. namile Türkçe, Parsçe ve ordu'ce ü ḑ dilde mecmue çılkermał̌ başladı . $936 \mathrm{da}$ madd imkensizliktan faaliyetini tetil eden bu neşriyat yerine 937 sonunda -Fercüman, çlktı. U̧̧ dilde çıken ve Hindıstanın şereitine göre diöer yerli matbuat gibi tas basmasile tab'edilen bu neşriycttan maada Cinin bu günkü merke-

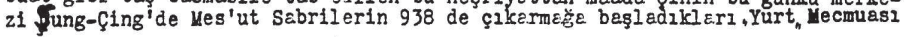
da şeralte göre uuhacir uillı neşriyetından seyllabilir bir mecmuadır. Türkistan muhecirlerinin bu neşriyatı sado bir ulkeye münhasır kalmamış kendi dertleri meyenında. Türk dünyesınden $d \varepsilon$. heberler dercederek hususen bu günkü Türkigeyi muhecirlere tenı tmă̌s çદlışmış, her iki Türkistanın müß̧terek fikir ve hereket organı olmuşl: rdır.

Kaynak: Cumhurbaşkanlığı Devlet Arşivi: Fon Kodu: 490.1.0/ Yer No: 1197.194.1 


\title{
The General Situation of East Turkestan in the First Years of the Republic and Cultural Relations with Turkey According to Archival Documents ${ }^{*}$
}

\section{Muzaffer Başkaya**}

\begin{abstract}
The founders of the Republic of Turkey took some steps after the declaration of the Republic to develop political and cultural co-operation with the Turks scattered around various parts of the world. For this purpose, situations of the cognates living there were taken a close interest and reports were prepared by those who know the region well. One of these reports is the report written by Mecdettin Delil. In this report, detailed information on the current political, economic and cultural situation of East Turkestan was given, especially the situation of the immigrants migrating out of Turkestan was emphasized and it was stated that cultural ties between Turkey and East Turkestan should be strengthened. Following this report, the Turkish government acted to introduce a new regime to Turkish elements living in the region and to build a bridge of sympathy with them. For this purpose, new letters were sent to the region, students were brought from there to be educated in Turkey, and newspapers and magazines were published in the region to advertise Turkey. Thus, hand of friendship was offered to the cognates living under the Chinese sovereignty, and the pressure of the Chinese administration, which wanted to establish its own hegemony in this region, was tried to be broken.
\end{abstract}

\section{Keywords}

Eastern Turkestan, immigrant, press, Latin characters, culture, advertisement.

\footnotetext{
Date of Arrival: 21 Nisan 2017 - Date of Acceptance: 07 Şubat 2018

You can refer to this article as follows:

Başkaya, Muzaffer (2019). "Arşiv Belgelerine Göre Cumhuriyetin İlk Yıllarında Doğu Türkistan’ın Genel Durumu ve Türkiye ile Kültürel Münasebetler" bilig - Journal of Social Sciences of the Turkic World 89: 215-236.

${ }^{*}$ Dr. Lecturer., Trabzon University, Fatih Faculty of Education, Department of Turkish and Social Sciences Education - Trabzon/Turkey

ORCID ID: https://orcid.org/0000-0002-4593-0979

mbaskaya61@gmail.com.tr
} 


\title{
Положение Восточного Туркестана в первые годы Турецкой Республики и культурные связи с Турцией по данным архивов Музафффер Башкая"
}

\begin{abstract}
Аннотация
Через некоторое время после провозглашения Турецкой Республики ее основателями были предприняты шаги, направленные на развитие социальных и культурных взаимоотношений с тюркоязычными народами, разбросанными по разным регионам. Для этого лицам, изучающим и хорошо знающим эти регионы, было дано указание собрать сведения о положении Восточного Туркестана и населяющих его тюркоязычных народах. Один из отчетов об этом был подготовлен Медждеттином Делилем. В этом отчете представлены подробные сведения о социальном, экономическом и культурном состоянии Восточного Туркестана на тот период, обращено внимание на положение переселенцев, покидающих Туркестан, указано на необходимость укрепления культурных связей Турции и Восточного Туркестана. После этого отчета турецкое правительство принялось знакомить живущих в этом регионе тюрков с новым режимом, искать к ним подход. Им был предложен новый алфавит, было обеспечено обучение в Турции для желающих получить образование, в регионе печатались газеты и журналы - все с целью рассказать как можно больше о Турции. Таким образом, тюркоязычным народам, живущим под покровительством Китая, была протянута рука дружбы и сделано все возможное, чтобы сломить влияние правительства Китая, пытавшегося установить в этом регионе свою гегемонию.
\end{abstract}

\section{Ключевые слова}

Восточный Туркестан, переселенец, средства массовой информации, латиница, культура, ознакомление.

\footnotetext{
Поступило в редакцию: 21 апреля 2017 г. - Принято в номер: 07 февраля 2018 г. Ссылка на статью:

Başkaya, Muzaffer (2019). “Arşiv Belgelerine Göre Cumhuriyetin İlk Yıllarında Doğu Türkistan'ın Genel Durumu ve Türkiye ile Kültürel Münasebetler”. bilig - Журнал Гуманитарных Наук Тюркского Мира 89: 215-236.

** Д-р, преподаватель / Трабзонский Университет, Педагогический Факультет имени Фатиха / кафедра турецкого языка и общественных наук - Трабзон / Турция ORCID ID: https://orcid.org/0000-0002-4593-0979 mbaskaya61@gmail.com.tr
} 